\title{
Faktor yang Berhubungan dengan Tingkat Kecemasan Perawat dalam Penanganan Pasien Covid-19 di Rumah Sakit Siloam Makassar
}

\author{
Anastasia Astin ${ }^{1}$, Aprilianti Paembonan ${ }^{2}$ \\ ${ }^{1,2}$ Rumah Sakit Siloam Makassar
}

\begin{tabular}{l}
\hline Info Artikel \\
\hline Riwayat Artikel: \\
Received : 14 Juni 2021 \\
Revised : 20 Juni 2021 \\
Accepted : 23 Juni 2021 \\
\hline
\end{tabular}

\section{Kata Kunci:}

Covid 19

Kecemasan

Perawat

\begin{abstract}
ABSTRAK
Penularan virus corona yang sangat cepat dan penambahan jumlah kasus yang secara signifikan terus meningkat dari hari ke hari menyebabkan petugas medis sebagai garda depan mengalami banyak tekanan akibat meningkatnya beban kerja, sehingga menimbulkan rasa khwatir mengenai kesehatan mereka bahkan merasa khwatir dapat menularkan virus tersebut ke orang lain terutama untuk keluarga mereka. Hal ini menimbulkan adanya perasaan takut dan cemas dari para tenaga medis yang merawat pasien Covid-19.Tujuan penelitian untuk mengetahui faktor yang berhubungan dengan kecemasan perawat dalam penanganan pasien Covid-19 di Rumah Sakit Siloam Makassar yang dilaksanakan pada bulan januari sampai februari 2021. Penelitian dilakukan menggunakan pendekatan cross-sectional study dengan teknik pengambilan sampel total sampling dengan jumlah sampel 50. Pengambilan data menggunakan kuesioner zung self-anxiety scale (ZSAS). Uji statistik yang digunakan yaitu uji chi- square dengan tingkat kemaknaan berdasarkan nilai $\propto($ alpa $)=0,05$ dan diperoleh hasil kepercayaan terhadap penggunaan APD dengan nilai $\mathrm{p}=0,004$, usia nilai $\mathrm{p}=0,000$ dan status perkawinan nilai $\mathrm{p}=$ 0,001 . Hasil penelitian ini menunjukkan bahwa terdapat hubungan kepercayaan terhadap penggunaan Alat Pelindung Diri (APD), usia dan status perkawinan dengan tingkat kecemasan perawat dalam penangan covid 19.
\end{abstract}

\section{Corresponding Author:}

Anastasia Astin,

Perawat Pelaksana, Rumah Sakit Siloam Makassar,

Jl. Metro Tj Bunga, No Kav 9, Tj Merdeka, Makassar, Indonesia.

Email: anastasiaastin160@gmail.com

\section{PENDAHULUAN}

Covid-19 adalah penyakit yang disebabkan oleh virus jenis baru yaitu virus corona. Pada manusia, virus ini dapat menyebabkan penyakit mulai dari gejala ringan hingga gejala yang serius. Gejala yang umum yang sering dijumpai karena virus ini berupa infeksi pada jalan napas mulai dari flu hingga penyakit serius seperti middle east respiratory syndrome (MERS) dan sindrom pernapasan akut berat / Severe Acute Respiratory Syndrome (SARS) (Wulandari et al., 2020).

Virus Corona dapat menular melalui percikan cairan atau lendir dari saluran pernafasan, sentuhan langsung dan benda yang terkontaminasi oleh virus tersebut dari orang yang satu ke orang lain (Repici et al., 2020). Resiko penularan tertinggi terjadi pada hari pertama, dikarenakan banyaknya virus di lendir yang pekat. Virus ini dapat menular ke orang lain secara langsung dalam waktu 48 jam sebelum gejala timbul dan sampai 14 hari setelah munculnya gejala. Selain dari pada itu, kontak erat dan lama dengan pasien yang terinfeksi oleh virus Covid-19 dapat menyebabkan tingginya resiko penularan virus (Isbaniah et al., 2020).

Menurut Daud A et al (2020), mereka yang terpapar langsung virus, memiliki daya tahan tubuh lemah dan mempunyai penyakit komorbid merupakan faktor yang paling dominan untuk ikut tertular oleh virus Covid-19. Disamping itu, perawat yang menangani pasien dengan Covid-19 dan memiliki kontak yang lama dengan pasien, tentunya perawat mempunyai peluang yang sangat besar untuk terpajan langsung dengan virus Covid-19. Maka dari itu, sangat penting bagi perawat untuk menggunakan alat pelindung diri (APD) untuk mencegah penularan virus.

Terkait dengan penggunaan APD, penelitian Fadli et al (2020) menyatakan bahwa dalam masa pandemi Covid-19 ini, petugas kesehatan mengalami kecemasan dalam menjalankan tugas terutama dalam hal penggunaan APD yang digunakan ketika menangani pasien. Ditinjau dari kasus pasien Covid-19 yang terus 
meningkat dan juga banyaknya perawat yang ikut tertular saat menjalankan tugasnya, membuat beberapa dari petugas kesehatan merasa cemas dan kurang percaya terhadap penggunaan APD yang mereka kenakan. Berdasarkan laporan dari world health organization (WHO) bahwa petugas kesehatan yang ikut mengalami infeksi karena virus corona jumlahnya sudah lebih dari 22.000 orang dan itu sudah tersebar di 52 negara ketika merawat dan menangani pasien (Lubis, 2020).

Selain dari pada itu, ada beberapa faktor yang dapat mempengaruhi kecemasaan perawat saat menangani pasien Covid1-19. Menurut penelitian yang dilakukan oleh Fadli et al (2020), ia menemukan bahwa APD, usia, status keluarga, dan kejujuran pasien memiliki pengaruh tehadap kecemasan perawat saat menangani pasien Covid-19. Covid-19 sudah ditetapkan oleh WHO (world health organization, 2020) sebagai kasus yang meresahkan dunia karena telah menjadi kedaruratan kesehatan masyarakat (KKMMD). Dilaporkan total kasus konfirmasi sebanyak 36.200.813 dengan 1.056.493 kematian (4,4\%). Pada 07 Oktober 2020 data dari (Kemenkes RI, 2020), jumlah kasus konfirmasi Covid-19 di seluruh Indonesia sebanyak 321.000. Selain dari pada itu, berdasarkan data dari DINKES Provinsi Sulawesi Selatan, (2020) sebanyak 16.085 dengan kasus kematian $427(2,7 \%)$. Berdasarkan jumlah tersebut dapat disimpulkan bahwa angka kejadian Covid-19 memang sangat tinggi dan proses penyebaran yang sangat cepat.

Berdasarkan uraian di atas, maka tujuan dari penelitian ini adalah untuk mengetahui dan mengidentifiaksi faktor yang berhubungan dengan kecemasan perawat tekait dengan faktor kepercayaan perawat terhadap alat pelindung diri, usia dan status perkawinan dalam penanganan pasien Covid-19 di Rumah Sakit Siloam Makassar.

\section{METODE PENELITIAN}

Penelitian ini merupakan jenis penelitian kuantitatif yang menggunakan analitik observasional dengan menggunakan pendekatan cross-sectional study. Populasi dalam penelitian ini adalah perawat yang bertugas menangani pasien Covid-19 di Rumah Sakit Siloam Makassar, yang berjumlah sebanyak 50 orang. Pengambilan sampel dalam penelitian ini menggunakan teknik total sampling dimana peneliti mengambil jumlah keseluruhan perawat yang menangani pasien Covid-19 di Rumah Sakit Siloam Makassar. Penelitian ini berfokus untuk mengetahui kecemasan perawat dalam penanganan pasien Covid-19 dengan menggunakan kuesioner Zung Self-anxiety Scale (ZSAS) yang berisi daftar pernyataan untuk mengukur tingkat kecemasan pada perawat yang menangani pasien Covid-19 di Rumah Sakit Siloam Makassar. Analisis data menggunakan uji chi-square.

\section{HASIL}

Tabel 3.1. Analisis Bivariat Faktor Yang Berhubungan Dengan Kecemasan Perawat

\begin{tabular}{|c|c|c|c|c|c|c|c|c|c|c|c|}
\hline \multirow[t]{2}{*}{ Variabel } & \multicolumn{2}{|c|}{$\begin{array}{l}\text { Cemas } \\
\text { Ringan }\end{array}$} & \multicolumn{2}{|c|}{$\begin{array}{l}\text { Cemas } \\
\text { Sedang }\end{array}$} & \multicolumn{2}{|c|}{$\begin{array}{l}\text { Cemas } \\
\text { Berat }\end{array}$} & \multicolumn{2}{|c|}{ Panik } & \multicolumn{2}{|c|}{ Total } & $\mathbf{P}$ \\
\hline & $\mathrm{f}$ & $\%$ & $\mathrm{~F}$ & $\%$ & $\mathrm{~F}$ & $\%$ & $\mathrm{f}$ & $\%$ & $\mathrm{~N}$ & $\%$ & 0.04 \\
\hline \multicolumn{12}{|l|}{$\begin{array}{l}\text { Kepercayaan terhadap } \\
\text { APD }\end{array}$} \\
\hline $\mathrm{Ya}$ & 14 & 28 & 10 & 20 & 7 & 14 & 0 & 0 & 31 & 62 & \\
\hline Tidak & 1 & 2 & 4 & 8 & 13 & 26 & 1 & 2 & 19 & 38 & \\
\hline \multicolumn{12}{|l|}{ Usia } \\
\hline Remaja Akhir (21-25) & 0 & 0 & 0 & 0 & 19 & 38 & 1 & 2 & 20 & 40 & 0.00 \\
\hline Dewasa Awal (26-35) & 15 & 30 & 14 & 28 & 1 & 2 & 0 & 0 & 30 & 60 & \\
\hline \multicolumn{12}{|l|}{ Status Perkawinan } \\
\hline Belum Menikah & 14 & 28 & 2 & 4 & 7 & 14 & 1 & 2 & 24 & 48 & 0.01 \\
\hline Sudah Menikah & 1 & 2 & 12 & 24 & 13 & 26 & 0 & 0 & 26 & 52 & \\
\hline
\end{tabular}

Berdasarkan tabel 3.1 di atas menunjukkan bahwa sebagian besar tingkat kecemasan yang dialami oleh perawat yang menangani pasien Covid-19 adalah cemas berat sebanyak 40\%. Dari 31 responden yang percaya terhadap penggunaan alat pelindung diri (APD), yang mengalami cemas ringan sebanyak 14 (28\%), cemas sedang sebanyak 10 (20\%), cemas berat sebanyak 7 (14\%) dan tidak ada yang mengalami panik. Sedangkan untuk responden yang tidak percaya terhadap penggunaan alat pelindung diri (APD) sebanyak 19 $(38 \%)$, dimana hanya $1(2 \%)$ yang mengalami cemas ringan, cemas sedang sebanyak $4(8 \%)$, cemas berat sebanyak 13 (26\%), dan yang mengalami panik sebanyak 1 (2\%). Dari 20 responden yang berusia 21-25 tahun 
(remaja akhir) tidak ada responden yang mengalami cemas ringan maupun cemas sedang. Berdasarkan usia, menunjukkan bahwa yang mengalami cemas berat sebanyak 19 (38\%) dan yang mengalami panik 1 (2\%). Sedangkan perawat yang berusia 26-35 (dewasa awal), yang mengalami cemas ringan sebanyak 15 (30\%), cemas sedang sebanyak 14(28\%), cemas berat sebanyak 1 (2\%) dan tidak ada responden yang mengalami panik pada usia dewasa akhir. Sedangkan untuk responden yang belum menikah, ada 24 responden yang mengalami cemas ringan sebanyak 14 (28\%), cemas sedang 2 (4\%), cemas berat sebanyak 7 (14\%) dan yang mengalami panik $1(2 \%)$ sedangkan responden yang telah menikah sebanyak 26 responden sehingga dapat dideskripsikan bahwa $1(2 \%)$ yang mengalami cemas ringan, responden yang mengalami cemas sedang sebanyak $12(24 \%)$, yang mengalami cemas berat $13(26 \%)$, dan tidak ada yang mengalami panik.

\section{DISKUSI}

\subsection{Hubungan Faktor Kepercayaan Terhadap Penggunaan Alat Pelindung Diri (APD) dengan Tingkat Kecemasan Perawat Pasien Covid-19.}

Kepercayaan terhadap alat pelindung diri merupakan keyakinan seorang perawat akan fungsi dari alat pelindung diri yang dikenakannya untuk melindunginya dari paparan Covid-19. Menurut Teher et al, (2020) alat pelindung diri merupakan sejumlah peralatan yang dipakai tenaga medis dalam bekerja agar terhindar dari resiko penularan virus atau penyakit. Berdasarkan hasil penelitian yang dilakukan oleh Handayani et al (2020) yang menghubungkan alat pelindung diri dengan kecemasan perawat bahwa meskipun perawat sudah menggunakan alat perlindungan diri tidak menutup kemungkinan mereka masih bisa beresiko untuk ditulari oleh pasien terutama ketika mereka sedang mengatur posisi pasien, menyeka keringatnya, ataupun saat mebuka baju pasien. Penularan virus dapat terjadi melalui droplet, atau aerosol dari pasien Covid19 dapat masuk melalui celah yang terbentuk tanpa disengaja oleh petugas kesehatan.

Berdasarkan hasil penelitian yang diperoleh dari pengambilan sampel di Rumah Sakit Siloam Makassar, dengan menggunakan uji statistik chi-square dan dilanjutkan dengan uji alternatif kolmogorof smirnov, maka diperoleh nilai $\mathrm{p}=0,04$ sehingga $\mathrm{p}<\propto$ maka dapat disimpulkan bahwa ada hubungan antara kepercayaan terhadap penggunaan alat pelindung diri dengan kecemasan perawat dalam menangani pasien Covid-19 di Rumah Sakit Siloam Makassar.

Menurut Teher et al, (2020) alat pelindung diri merupakan sejumlah peralatan yang dipakai tenaga medis dalam bekerja agar terhindar dari resiko penularan virus atau penyakit. Alat pelindung diri yang digunakan berupa; gown cover all disposable digunakan sebagai pelindung dari ancaman penularan mikroorganisme pathogen: virus, bakteri dan jamur, masker N-95 agar partikel kecil yang ada di udara (aerosol) tidak masuk lewat mulut dan hidung petugas kesehatan, face shield melindungi wajah petugas kesehatan dari ancaman partikel kecil yang ada di udara, surgical mask berfungsi melindungi selaput lendir hidung, mulut, saat melakukan tindakan atau perawatan pasien dari percikan, head cup untuk menutupi kepala petugas kesehatan dari mikroorganisme serta untuk menvegah setiap kotoran dari rambut petugas jatuh di saat melakukan tindakan, kacamata (google) berfungsi melindungi mata dari semua jenis cairan pasien, sepatu boots berfungsi menutupi bagian kaki bagian kaki petugas kesehatan dari tetesan cairan pasien yang ada di lantai serta menjaga petugas kesehatan dari peralatan ataupun tindakan medis yang bisa menimbulkan cedera, dan handscoon berfungsi untuk melindungi tangan petugas kesehatan dari percikan atau sentuhan langsung dengan cairan tubuh pasien, secret, ekskreta, dan peralatan yang sudah digunakan pada pasien.

Ditinjau dari fungsi alat pelindung diri yang mampu melindungi perawat dari paparan virus saat menangani pasien Covid-19, masih ada juga perawat yang tidak percaya terhadap alat pelindung diri yang dikenakannya. Ketidakpercayaan perawat terhadap alat pelindung diri bisa dikaitkan dengan laporan dari world health organization (WHO) bahwa petugas kesehatan yang ikut mengalami infeksi karena virus corona jumlahnya sudah lebih dari 22.000 orang dan itu sudah tersebar di 52 negara ketika merawat dan menangani pasien (Lubis, 2020). Dari pernyataan tersebut dapat disimpulkan bahwa tingginya angka petugas medis yang terinfeksi saat menghadapi pasien Covid-19 bisa menjadi pemicu sebagian perawat untuk tidak percaya terhadap alat pelindung diri yang dikenakannya saat merawat pasien Covid-19.

Berdasarkan hasil penelitian yang disimpulkan oleh peneliti bahwa ketidakpercayaan perawat terhadap penggunaan alat pelindung diri yang dikenakan dapat dipengaruhi oleh banyaknya kejadian atau informasi yang didapatkan bahwa meskipun telah menggunakan alat pelindung diri secara lengkap, kenyataanya masih banyak tenaga medis yang terinfeksi oleh virus saat menangani pasien Covid-19. Hal inilah yang memicu timbulnya rasa cemas pada perawat lainnya.

\subsection{Hubungan Faktor Usia Dengan Tingkat Kecemasan Perawat Dalam Menangani Pasien Covid-19.}

Usia adalah salah satu faktor yang ikut berpengaruh terhadap kecemasan seseorang, karena di saat usia semakin bertambah, maka kematangan psikologi dari orang tersebut semakin baik, artinya semakin matang psikologi seseorang maka akan semakin baik pula adaptasi terhadap kecemasan. Menurut Tambengi et al (2019), usia muda akan lebih mudah menderita cemas dibandingkan dengan mereka yang berusia tua, hal 
tersebut terjadi karena usia berkaitan dengan pengalaman dan pandangan seseorang terhadap sesuatu, semakin bertambah usia seseorang maka semakin bertambah juga pengalaman dalam berfikir bertindak.

Berdasarkan hasil penelitian yang diperoleh dari pengambilan sampel di Rumah Sakit Siloam Makassar, dengan menggunakan uji statistik chi-square dan dilanjutkan dengan uji alternatif kolmogorof smirnov, maka diperoleh nilai $\mathrm{p}=0,00$ sehingga $\mathrm{p}<\propto$ maka dapat disimpulkan bahwa ada hubungan antara usia dengan kecemasan perawat dalam menangani pasien Covid-19 di Rumah Sakit Sioloam Makassar.

Menurut Kaplan et al (2010) dalam Anita (2019) kecemasan adalah suatu tanggapan dari diri seseorang terhadap suatu hal yang dianggapnya berbahaya tetapi bisa juga menjadi hal normal yang bisa mengubah, mengembangkan, memberikan pengalaman serta dapat membuat seseorang untuk menemukan jati diri dan hidupnya. Usia adalah salah satu faktor yang ikut berpengaruh terhadap kecemasan seseorang, karena disaat usia semakin bertambah, maka kematangan psikologi dari orang tersebut semakin baik, artinya semakin matang psikologi seseorang maka akan semakin baik pula adaptasi terhadap kecemasan (Linggi et al., 2020)

Menurut Vellyana et al (2017) usia juga erat kaitannya dengan tingkat perkembangan seseorang dan kemampuan koping terhadap kecemasan, semakin dewasa usia seseorang maka semakin matang proses berpikirnya terhadap suatu masalah yang dialaminya. Hasil dari penelitian yang dilakukan oleh Furwanti (2014) menunjukkan bahwa $(56,0 \%)$ responden dengan usia $<30$ tahun mengalami cemas berat, sedangkan kecemasan ringan lebih banyak dialami oleh responden dengan usia > 50 tahun yaitu sebanyak $(69,2 \%)$ responden. Usia yang semakin bertambah akan membuat seseorang banyak mendapat banyak pengalaman yang lebih baik untuk mengatasi kecemasannya. Hal ini dikarenakan usia berkaitan dengan pengalaman dan pandangan terhadap sesuatu, semakin bertambah usia seseorang maka semakin bertambah juga pengalaman dalam berfikir bertindak.

Berdasarkan hasil penelitian diatas, peneliti berasumsi bahwa semakin dewasa usia seseorang, maka semakin berkurang kecemasan yang dialami. Hal tersebut bisa terjadi karena semakin dewasa usia seseorang maka semakin matang proses berpikirnya dalam menghadapi suatu masalah. Selain dari pada itu, pengalaman seseorang terhadap suatu masalah yang pernah dialami akan memberikan perubahan atau perkembangan dalam hidupnya, sehingga ketika menghadapi suatu masalah yang sama seseorang tersebut dapat mengontrol kecemasan yang dialami.

Sebaliknya, dalam penelitian ini ada juga responden dewasa awal yang mengalami cemas berat hal ini disebabkan karena mereka takut akan resiko jika sampai tertular. Covid-19 ini merupakan suatu kasus baru dan proses penularan dari penyakit ini juga sangat cepat sehingga menyebabkan masih ada responden yang cemas berat sekalipun usia mereka sudah dalam kategori dewasa awal karena mereka juga belum pernah mengalami hal tersebut dan belum memiliki pengalaman sama sekali dengan kasus ini.

\subsection{Hubungan Faktor Status Pernikahan Dengan Tingkat Kecemasan Perawat Dalam Menangani Pasien Covid-19.}

Menurut Prihandhany., (2015) Status pernikahan merupakan derajat kedudukan seseorang dalam suatu masyarakat mengenai tanggung jawab yang di pegang sebagai peran dalam rumah tangganya. Atau dengan kata lain status pernikahan merupakan individu yang tinggal berkelompok dalam satu rumah yang memiliki tanggung jawab masing-masing.

Berdasarkan hasil penelitian yang telah dilakukan terhadap perawat yang bertugas dalam penanganan pasien Covid-19 di Rumah Sakit Siloam Makassar, yang dianalisis menggunakan uji statistic chi-square dan dilanjutkan dengan uji alternatif kolmogorof smirnov, maka diperoleh nilai $\mathrm{p}=0,01$ sehingga $\mathrm{p}<\propto$ maka dapat disimpulkan bahwa ada hubungan antara status pernikahan dengan kecemasan perawat dalam menangani pasien Covid-19 di Rumah Sakit Siloam Makassar.

Dari hasil penelitian yang dilakukan terhadap responden terdapat cemas berat lebih banyak dialami oleh responden yang sudah menikah dibandingkan dengan responden yang belum menikah. Hal ini sejalan dengan penelitian yang dilakukan oleh Fadli et al (2020) bahwa status tenaga kesehatan yang sudah berkeluarga lebih merasa cemas dibandingkan dengan tenaga kesehatan yang belum berkeluarga.

Menurut Repici et al (2020) virus Covid-19 dapat menular dari orang yang terinfeksi oleh virus tersebut ke orang lain melalui cairan, sentuhan langsung dan benda yang terkontaminasi. Sebagai tenaga medis, perawat adalah garda terdepan yang menangani pasien Covid-19 yang mengalami kontak waktu yang lama dengan pasien sehingga tentunya perawat mempunyai peluang yang sangat besar untuk terpajan langsung dengan virus Covid-19 dan bahkan bisa menjadi rantai untuk menularkan virus Covid-19 terhadap orang lain terutama orang terdekatnya. Hal inilah yang memicu kecemasan bagi perawat yang sudah menikah bahwa sewaktu - waktu mereka dapat menularkan virus Covid-19 terhadap istri atau suami dan anak mereka. Hal ini juga didukung oleh pernyataan MHPSS Group, (2020) bahwa salah satu penyebab tenaga kesehatan mengalami rasa cemas saat merawat pasien Covid-19 yaitu rasa takut akan menularkan virus tersebut pada teman dan keluarga. 
Sebaliknya dari hasil penelitian yang dilakukan terhadap perawat yang menangani pasien Covid-19 ada juga responden yang belum menikah tetapi mengalami cemas berat dan merasa panik. Setelah dilakukan observasi terhadap perawat yang bertugas menangani pasien Covid-19 di Rumah Sakit Siloam Makassar, salah satunya penyebabnya yaitu karena usia. Kebanyakan responden yang belum menikah adalah mereka yang masuk dalam kategori usia remaja akhir.Disamping itu juga ada responden yang sudah menikah tetapi hanya mengalami cemas ringan, hal ini disebabkan karena selama mereka bertugas mereka tinggal terpisah dari keluarga, sehingga resiko mereka untuk menularkan virus kepada kaluarga mereka sangat rendah.

Berdasarkan observasi yang dilakukakan di lapangan terhadap responden di Rumah Sakit Siloam Makassar, mereka juga tetap pulang ke rumah bertemu keluarga jika mereka sedang tidak bertugas tetapi mereka selalu memastikan kondisi mereka aman sebelum pulang yaitu dengan melakukan pemeriksaan secara rutin dan untuk mereka yang bekerja di zona merah, dilakukan pemeriksaan secara rutin setiap 5 hari sehingga perawat tersebut juga dapat memantau kondisi kesehatannya.

\section{KESIMPULAN}

Hasil penelitian ini menunjukkan bahwa terdapat hubungan kepercayaan terhadap penggunaan Alat Pelindung Diri (APD), usia dan status perkawinan dengan tingkat kecemasan perawat dalam penangan covid 19.

\section{UCAPAN TERIMA KASIH}

Terimakasih kami ucapkan kepada pihak Rumah Sakit Siloam Makassar yang telah memberikan ijin dan memfasilitasi penelitian ini, juga kepada rekan rekan sejawat yang telah bersedia berpartisipasi sebagai responden dalam penelitian ini.

\section{REFERENSI}

Anita. (2019). pemberian terapi musik klasik Mozart terhadap kecemasan pasien pre operasi dengan anestesi umum. 825.

Anwar Daud, Aminuddin Syam, .A.Arsunan Arsin, S. S. H. (2020). penanganan coronavirus (COVID-19) Ditinjau Dari Perspetikf Kesehatan Masyarakat (A. G. \& T. Gosyen (ed.); 1st ed.). Gosyen Publishing.

Dinas Kesehatan Provinsi Sulawesi Selatan. (2020). COVID-19 Di Sulawesi Selatan. 07 Oktober.

Elan Furwanti. (2014). Gambaran Tingkat Kecemasan Pasien Di Instalasi Gawat Darurat (Igd) Rsud Panembahan Senopati Bantul. Gambaran Tingkat Kecemasan Pasien Di Instalasi Gawat Darurat, 7(2).

Fadli, F., Safruddin, S., Ahmad, A. S., Sumbara, S., \& Baharuddin, R. (2020a). Faktor yang Mempengaruhi Kecemasan pada Tenaga Kesehatan Dalam Upaya Pencegahan Covid-19. Jurnal Pendidikan Keperawatan Indonesia, 6(covid19), 61. https://doi.org/10.17509/jpki.v6i1.24546

Henny Tambengi et al. (2019). Hubungan waktu tunggu dengan kecemasan pasien di unit gawat darurat di rumah sakit umum. Journal of Chemical Information and Modeling, 53(9), 1689-1699.

Kementrian Kesehatan Republik Indonesia. (2020). Situasi Terkini Perkembangan Coronavirus Disease (COVID-19) 07 Oktober 2020. 07 Oktober, 1.

Linggi, E. B., Wirmando., Kurnia, M., \& Tandi, N. (2020). Pengaruh Pemberian Virgin Coconut Oil (VCO) Terhadap Luka Dekubitus Pada Pasien Tirah Baring Lama di RS. Stella Maris Makassar. Jurnal Penelitian Kesehatan Suara Forikes, 12 (Januari), 120-123.

MHPSS Reference Group. (2020). Catatan Tentang Aspek Kesehatan Jiwa dan Psikososial Wabah Covid. Iasc, Feb, 1-20.

Repici, A., Maselli, R., Colombo, M., Gabbiadini, R., Spadaccini, M., Anderloni, A., Carrara, S., Fugazza, A., Di Leo, M., Galtieri, P. A., Pellegatta, G., Ferrara, E. C., Azzolini, E., \& Lagioia, M. (2020). Coronavirus (COVID-19) outbreak: what the department of endoscopy should know. Gastrointestinal Endoscopy, 92(1), 192-197. https://doi.org/10.1016/j.gie.2020.03.019

Prihandhany, E. A. (2015). Fear Of Success Ditinjau Dari Status Pernikahan (Studi Komparasi Pada Wanita Pekerja).

Rina Tri Handayani et al. (2020). Faktor penyebab stres pada tenaga kesehatan dan masyarakat saat pandemi covid-19. $8(3), 353-360$.

Vellyana, D., Lestari, A., \& Rahmawati, A. (2017). Faktor-Faktor yang Berhubungan dengan Tingkat Kecemasan pada Pasien Preoperative di RS Mitra Husada Pringsewu. Jurnal Kesehatan, 8(1), 111. https://doi.org/10.26630/jk.v8i1.403

World health organization (WHO). (2020). Coronavirus disease (COVID-19) pandemic. 30 Januari, 1

Wulandari, A., Rahman, F., Pujianti, N., Sari, A. R., Laily, N., Anggraini, L., Muddin, F. I., Ridwan, A. M., Anhar, V. Y., Azmiyannoor, M., \& Prasetio, D. B. (2020). Hubungan Karakteristik Individu dengan Pengetahuan tentang Pencegahan Coronavirus Disease 2019 pada Masyarakat di Kalimantan Selatan. Jurnal Kesehatan Masyarakat Indonesia, 15(1), 43. https://doi.org/10.26714/jkmi.15.1.2020.42-46 